\title{
ANALISA PENGENDALIAN BIAYA DAN WAKTU DENGAN METODE KONSEP NILAI HASIL PADA PROYEK PEMBANGUNAN GEDUNG SATPOL PP KABUPATEN MAJALENGKA
}

\author{
Jahar Irawan'), Arief Rijaluddin'2), Eka Juliar ${ }^{3)}$ \\ Program Studi Teknik Sipil, Fakultas Teknik, Universitas Majalengka \\ email: jahar_irawan03@yahoo.com, aguzmilan22@gmail.com, lingga8689@gmail.com
}

\begin{abstract}
The success of a project can not be separated from a series of activities that include the stages of planning, implementation and supervision, so that the goals set can be achieved. In an effort to succeed in a construction project, a good technique or management method is needed to improve efficiency, productivity, and quality of work. In connection with that, it is necessary to carry out supervision and control measures in all sectors, especially control of costs and time.

This research was conducted at the Majalengka Regency Satpol PP Building Project which aims to determine the project's time performance and the estimated cost and time of the building construction project and the method of concept of the value of the results is effective or not. The data used in this study is the Time Schedule, Cost Budget Plan, and weekly progress reports. From these data can produce BCWP and BCWS values. ACWP, with the help of Microsoft Excel, obtained CP, SV, CPI, $S P I$, and predicts completion of project costs and end times (ETC, EAC and ECD).

From the results of the analysis of the time of the construction of the Satpol PP Building in Majalengka Regency until the 22nd week with a budget of Rp. 2,454,849,000, - resulting in a CPI of 1,1000, SPI obtained at 1,0266, EAC value of Rp. 2.23,681,459.98 and ECD amounted to 126, showing the estimated construction completion time of 126 days, which means the project progressed 24 days from the 150 day plan.
\end{abstract}

Keywords: Earned Value Method, BCWP, BCWS, ETC, EAC

\section{PENDAHULUAN}

Dewasa ini pembangunan sarana fisik di Kabupaten Majalengka semakin pesat seiring dengan digalakkannya modernisasi oleh pemerintah dengan tujuan menyongsong era globalisasi, dengan rencana pembangunan Gedung Satpol PP Kabupaten Majalengka perlu suatu pengelolaan yang serius, mengingat semakin besarnya ukuran proyek dan semakin kompleksnya ketergantungan antara satu bagian pekerjaan dengan pekerjaan yang lain dalam satu proyek untuk mencapai hasil yang diinginkan.

Keberhasilan suatu proyek tidak lepas dari serangkaian aktivitas yang meliputi tahapan perencanaan, pelaksanaan dan pengawasan, supaya tujuan yang telah ditetapkan dapat tercapai. Dalam usaha menyukseskan suatu proyek konstruksi diperlukan suatu teknik atau cara pengelolaan yang baik untuk meningkatkan efisiensi, produktivitas, dan kualitas kerja. Sehubungan dengan itu, maka perlu dilakukan tindakan pengawasan dan pengendalian di semua sektor, khususnya pengendalian biaya dan waktu.

Metode Konsep Nilai Hasil merupakan suatu metode yang digunakan pada teknik pengendalian waktu dan biaya proyek. Beberapa teknik pengendalian proyek selain Konsep Nilai Hasil antara lain adalah Kurva S (S-Curve), Identifikasi Varian, Analisa Kecenderungan dan Rekayasa Nilai (Value Engineering ). ( Widiasantri, 2013).

Dari penjelasan latar belakang di atas maka rumusan masalah yang dapat diambil adalah :

1. Apakah Metode Konsep Nilai Hasil efektif digunakan untuk mengendalikan Biaya dan Waktu pada proyek pembangunan gedung Satpol PP Kabupaten Majalengka ?

2. Bagaimanakah kinerja waktu proyek Pembangunan gedung satpol PP Kabupaten Majalengka dengan menggunakan metode konsep nilai hasil tersebut ?

3. Berapakah Perkiraan Biaya dan Waktu penyelesaian proyek sampai minggu akhir?

Pengertian proyek menurut Soehendardjati dan Dannayanti (2010) adalah sebagai berikut ini.

1. Proyek adalah suatu kegiatan terorganisir yang menggunakan sumber daya yang dijalankan selama jangka waktu yang 
terbatas yang mempunyai titik awal dimulainya dan titik akhir saat berakhirnya.

2. Proyek adalah usaha yang kompleks, biasanya kurang dari tiga tahun dan merupakan kesatuan dari tugas yang berhubungan dengan sasaran, jadwal, dan anggaran yang terumuskan dengan baik.

Manajemen proyek adalah suatu cara/metode untuk mencapai suatu hasil dalam bentuk bangunan, infrastruktur dengan menggunakan sumber daya yang secara efektif melalui tindakan-tindakan perencanaan, pelaksanaan, pengendalian, dan koordinasi suatu proyek dari awal (gagasan) hingga berakhirnya proyek untuk menjamin pelaksanaan proyek secara tepat waktu, tepat biaya, dan tepat mutu (Ervianto, 2002).

Metode pengendalian proyek yang digunakan adalah Metode Pengendalian Biaya dan Jadwal Terpadu (Konsep Nilai Hasil). Metode ini mengkaji kecenderungan Varian Jadwal dan Varian Biaya pada suatu periode waktu selama proyek berlangsung (Soeharto,1995).

Metode "Konsep Nilai Hasil"adalah suatu metode pengendalian yang digunakan untuk mengendalikan biaya dan jadwal proyek secara terpadu. Metode ini memberikan informasi status kinerja proyek pada suatu periode pelaporan dan memberikan informasi prediksi biaya yang dibutuhkan dan waktu untuk penyelesaian seluruh pekerjaan berdasarkan indikator kinerja saat pelaporan

Konsep nilai hasil adalah konsep menghitung besarnya biaya yang menurut anggaran sesuai dengan pekerjaan yang telah diselesaikan atau dilaksanakan (budgeted cost of works performed). Bila ditinjau dari jumlah pekerjaan yang diselesaikan maka berarti konsep ini mengukur besarnya unit pekerjaan yang diselesaikan, pada suatu waktu bila dinilai berdasarkan jumlah anggaran yang disediakan untuk pekerjaan tersebut. Dengan perhitungan ini diketahui hubungan antara apa yang sesungguhnya telah dicapai secara fisik terhadap jumlah anggaran yang telah dikeluarkan (Soeharto, 1995).

"Konsep Konsep Nilai Hasil untuk Pengelolaan Proyek Konstruksi" karya Soemardi B.W, dkk (2007)., di mana Fleming dan Koppelman menjelaskan perbedaan konsep Konsep Nilai Hasil dibandingkan dengan manajemen biaya tradisional.

Konsep nilai hasil dapat digunakan untuk digunakan untuk menganalisis kinerja dan membuar perkiraan pencapaian sasaran. Konsep nilai hasil menggunakan 3 indikator, yaitu BCWS (Budget Cost of Work Schedule) (Soeharto, 1995), BCWP (Budget Cost of Work Peformance), ACWP (Actual Cost of Work Peformance).

Studi pustaka berisi mengenai penelitian yang telah dilakukan sebelumnya mengenai analilsis konsep nilai hasil. Studi pustaka untuk penelitian ini meliputi :

1. Analisis Perencanaan Biaya Dan Waktu Dengan Metode Konsep Nilai Hasil Penelitian ini dilakukan oleh Suhermanto (2014), dengan pokok bahasan yang diteliti yaitu "Analisis Perencanaan Biaya \& Waktu Penyelesaian Proyek dengan Metode Konsep Nilai Hasil" pada proyek gedung PT Prima Andalan Group Jogjakarta.

2. Analisis Biaya Dan Waktu Proyek Pembangunan Kampus Politeknik Menggunakan Konsep Nilai Hasil Penelitian ini dilakukan oleh Filastri (2015), dengan pokok bahasan yang diteliti "Analisis Biaya dan Waktu Proyek Pembangunan Kampus Politeknik Menggunakan Konsep Nilai Hasil".

3. Evaluasi Pengendalian Biaya Dan Waktu Dengan Menggunakan Metode Konsep Nilai Hasil Pada Proyek Student Boarding House President University Penelitian ini dilakukan oleh Dinariana dan Mirawati (2011). Dengan studi kasus proyek pembangunan Student Boarding House President University, Bekasi, Jawa Barat. Tujuan dilakukan penelitian ini adalah untuk mengkaji dan melakukan evaluasi pada Proyek Student Boarding House President University dalam hal biaya dan waktu secara aktual berdasarkan data yang diperoleh.

\section{METODE PENELITIAN}

Metode penelitian merupakan tahapan penelitian yang dilakukan untuk menyelesaikan suatu masalah, sehingga penelitian sangat membantu untuk mengarahkan dalam menjawab permasalahan yang ada. Metode penelitian juga dapat memberikan alternatif penjelasan sebagai kemungkinan dalam proses pemecahan masalah. Metode yang digunakan untuk menentukan nilai hasil dan perkiraan akhir proyek menggunakan 
metode Konsep Nilai Hasil.

Objek yang digunakan dalam penelitian ini adalah proyek pembangunan Gedung Satpol PP Wilayah Kab.Majalengka, terletak di Jl. Raya Tonjong - Pinangraja No. 50, di Kelurahan Cicenang, Kecamatan Cigasong Kabupaten Majalengka, Jawa Barat

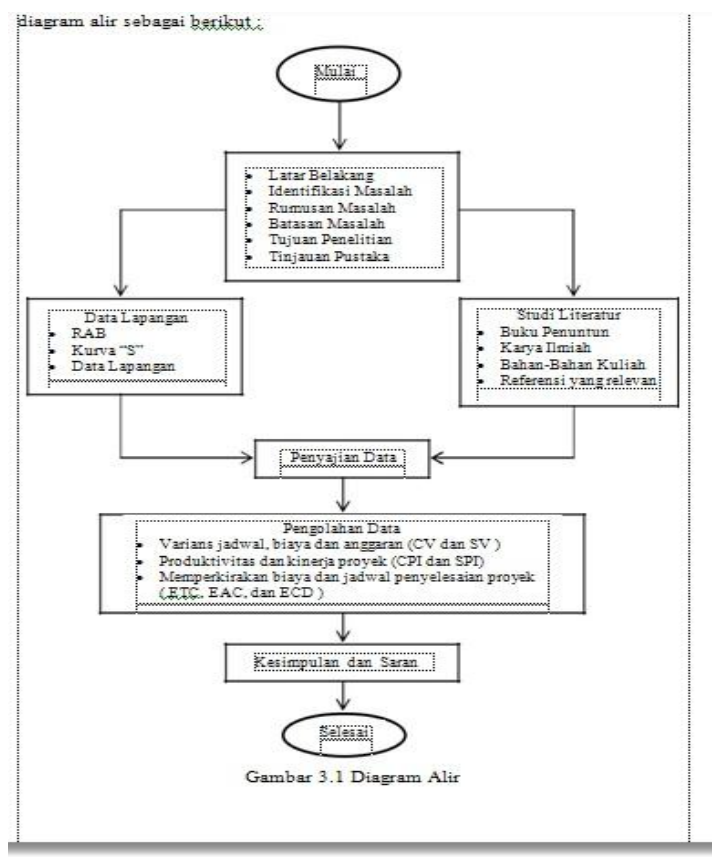

Gambar 1. Metode Pelaksanaan Penelitian

\section{Metode Pengumpulan Data}

Jenis data yang digunakan dalam penyusunan laporan Skripsi ini adalah data sekunder. Data sekunder adalah data yang lebih dulu dikumpulkan dan dilaporkan oleh orang atau instansi diluar data yang diolah sendiri, walaupun yang dikumpulkan itu sesungguhnya data yang asli. Data sekunder diperoleh dari instansi-instansi terkait seperti kontraktor CV.Pilar Perkasa dan dinas terkait yaitu Dinas BMCK Kabupaten Majalengka.

\section{HASIL DAN PEMBAHASAN}

Dalam perhitungan analisa manajemen menggunakan metode konsep nilai hasil yang akan dihitung adala $\mathrm{h}$ :

1. Budgeted Cost for Work Scheduled (BCWS)

2. Budgeted Cost For Work Performed (BCWP)

3. Actual Cost For Work Performed (ACWP)

4. Cost Variance (CV)

5. Schedule Variance (SV)
6. Cost Performance Index (CPI)

7. Schedule Performance Index (SPI)

8. Peramalan Menggunakan Earned Value Methods
a. Estimate to Completion
(ETC)
b. Estimate at Completion
(EAC)
c. Estimated Completion Date
(ECD)

\section{BCWS - Budgeted Cost for Work Scheduled \\ BCWS $=\frac{\text { Bobot Rencana per Ninggu }}{\text { Bobot Rencana Keseluruhan }}$. Anggaran Rencana}

\begin{tabular}{|c|c|c|c|c|c|c|}
\hline \multicolumn{7}{|c|}{ Tabel 1. Nilai BCWS } \\
\hline 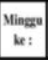 & 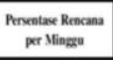 & 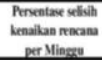 & $\begin{array}{l}\text { Bobot Rencan } \\
\text { Kescenturntan }\end{array}$ & Angeran Reroana & $\begin{array}{c}\text { всиу } \\
\text { комнит }\end{array}$ & всиммing \\
\hline 1 & 0.02053 & 0.0633 & 100,000 & 2451390.05998 & 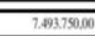 & 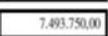 \\
\hline 2 & 3,730 & 3.457 & 10,0000 & $2454 \times 99.060 .98$ & 91.56800638 & 8405219,3 \\
\hline 3 & 7.1566 & 3,4857 & 100,000 & 2454.59 .06598 & $175.650 .18,77$ & 840521919.38 \\
\hline 4 & 11,730 & 4.504 & 10,000 & 245459.06598 & $28 \times 175552.16$ & 112991.383 .39 \\
\hline 5 & 18,009 & 6.639 & 10,000 & 24S4S459005989 & 44390.01627 & 156223.4 .4 .11 \\
\hline 6 & 20.1141 & 60112 & 100,000 & 2454890.05098 & $591.6383 \times 1505$ & 177560.85478 \\
\hline 7 & 28.438 & 4287 & 10,000 & 2454590.05989 & $608.766073,11$ & 100.822798 .06 \\
\hline 8 & 3.5135 & 42897 & 10,000 & 2454590.05059 & $799.684 .47,17$ & 1028282799,06 \\
\hline 9 & 3,9135 & 23700 & 100,000 & 244459.000598 & 85.5093658 & $88.17874,68$ \\
\hline 10 & 39297 & 4.2662 & 100,0000 & $2454 \times 9.00598$ & 9600960.58 & $10522034,4,73$ \\
\hline II & 2.20106 & 30,30 & 100,000 & 2454.59 .05998 & $1.038466334,63$ & 75.466 .64 .05 \\
\hline 12 & f.1511 & 4.854 & 10,0000 & 2451890.05998 & 1.157 .655019 .99 & 119.16865027 \\
\hline 13 & 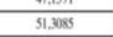 & 4.1515 & 100,000 & 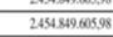 & 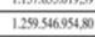 & 101.911.935, we \\
\hline 14 & 55,40000 & 4,1315 & 10,000 & 2 24S4599.60598 & $1366.55890,20$ & 101919193,500 \\
\hline 15 & 2.297 & 60778 & 10.000 & 20445990.0598 & 1524.0595959 .0 & 16298.968 .10 \\
\hline 16 & 60,0109 & 7,062 & 10,000 & 244489.05059 & 1.700 .725020 .717 & $179.365655,41$ \\
\hline 17 & $\pi, 0 \times \theta$ & 84630 & 100,000 & 24S4S490.65958 & 1911515214,13 & 200.752700 .42 \\
\hline 18 & 8.6050 & 7.86161 & 100,000 & 245499.00598 & $21003.399 .71,48$ & $191.87457,35$ \\
\hline 19 & 92.586 & 6.855 & 10.000 & 2451890.0559 & 2272.4185951 .66 & 160.09 .182 .28 \\
\hline \begin{tabular}{|l|}
$x$ \\
\end{tabular} & 97.1177 & 4.802 & 10,000 & 2445.990 .05998 & 2391.1314257 .68 & 118892500.5 \\
\hline 21 & 90.1819 & 1,702 & 100,000 & 2454.890 .05098 & $2.34 .673939,4$ & s.3.s5se, 7 \\
\hline$n$ & 10000000 & 0.8181 & 10,0000 & 244.990 .0598 & 2458996069 & $2000227 \times 4$ \\
\hline
\end{tabular}

Sumber : Hasil Perhitungan

BCWP - Budgeted Cost For Work Performed

BCIVP = $\frac{\text { Bobot Pelaksanan per.Vinggu }}{\text { Bobot Rencana Keseluruhan }}+$ Anggaran Rencana

Tabel 2. Nilai BCWP

\begin{tabular}{|c|c|c|c|c|c|c|}
\hline $\begin{array}{c}\text { Mingens" } \\
\text { ke: }\end{array}$ & $\begin{array}{c}\text { Persentase Realiusi } \\
\text { per Mingzu }\end{array}$ & 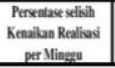 & $\begin{array}{l}\text { Bobot Rencana } \\
\text { Keseduruthan }\end{array}$ & Angaran Rencana & $\begin{array}{c}\text { BCWF } \\
\text { KoмtLITIF }\end{array}$ & BCWF/MINGGU \\
\hline 1 & 0.3699 & 0.3699 & 100,000 & 2454.899 .960 .98 & \begin{tabular}{l|l|}
9.667 .700 .39 \\
\end{tabular} & 9.066760 .39 \\
\hline 2 & 26116 & 22227 & 100,0000 & $2.454 .849 .606,98$ & 64.110 .472 .22 & 55063.711 .83 \\
\hline 3 & 6,3028 & 3,6912 & 100,0000 & 2454.899 .600 .98 & $154.723243,30$ & $90.612771,08$ \\
\hline 4 & 133046 & 78019 & 100,0000 & $2454.999 .606,98$ & 388830095.86 & 18.159 .85257 \\
\hline 5 & 18.0857 & 4.2811 & 100,0000 & 2.451 .899 .606 .98 & 439966,601,68 & 105.093561682 \\
\hline 6 & 24,7213 & 6.636 & 100,0000 & $2.451 .849,606,98$ & 60680060,45 & 162884068,77 \\
\hline 7 & 38,2259 & 13,5046 & 100,0000 & $2.454 .89,606,98$ & 938337.631,29| & $331.516,960,84$ \\
\hline 8 & 4,1899 & 89640 & 100,0000 & $2454.99,606,98$ & 1.158 .40 .176 .53 & $220.062545,23$ \\
\hline 9 & 533991 & 6.6992 & 100,000 & $2.454 .499,605,98$ & 1.321 .66781792 & 163.227 .641 .39 \\
\hline 10 & 615567 & 2.1177 & 100,000 & 2.45 .849 .606989 & $1511.125363,25$ & $189.577 .565,33$ \\
\hline II & 60,327 & 7.8359 & 1000000 & $2.454 .899 .606,98$ & 1.703 .466077 .62 & $192360.714,36$ \\
\hline 12 & 76.8091 & 7,4864 & 100,000 & $2454.899 .606,98$ & 1.887 .021262 .38 & $183535.184,77$ \\
\hline 13 & 81.9610 & 5,0919 & 100,000 & $2,454.999,605,98$ & 2012018593,91 & $124.97,331,52$ \\
\hline 14 & 856659 & 3,6829 & 100,000 & 2454.849 .606 .98 & 2102644111,77 & 90.655517786 \\
\hline 15 & 882.218 & 2.679 & 100,000 & 24.44 .94 .606598 & $2,167 ., 304001,00$ & 64.756 .289 .23 \\
\hline 16 & 89.6533 & 1.635 & 100,000 & $2454.849,606,98$ & $220.901 .692,99$ & 33.41 .29199 \\
\hline 17 & 90.3096 & 0.643 & 100,000 & $2454.849 .606,98$ & 2216.964 .419 .94 & 16.062776 .85 \\
\hline 18 & 923899 & 20093 & 100,0000 & 2454.49 .606989 & 226800931203 & $51.048922,19$ \\
\hline 19 & 97.6377 & 5,2688 & 100,000 & 2454.899 .60698 & $2396.858430,16$ & $128.899 .118,13$ \\
\hline$x$ & 10000000 & 2.623 & 100,000 & $2.454 .49,506,98$ & 2454.899605 .98 & $57.991 .175 \times 2$ \\
\hline
\end{tabular}

Sumber : Hasil Perhitungan

Computer Science | Industrial Engineering |Mechanic Engineering |Civil Engineering 


\section{ACWP - Actual Cost For Work Performed}

ACWP $=\frac{\text { Bobot Pelaksanaan per Minggu }}{\text { Bobot Rencana Keseluruhan }} *$ Anggaran Pelakssanaan

Tabel 3. Nilai ACWP

\begin{tabular}{|c|c|c|c|c|c|c|}
\hline $\begin{array}{c}\text { Minggu } \\
\text { ke: }\end{array}$ & \begin{tabular}{|c} 
Persentase Reallisasi \\
per Minggg
\end{tabular} & \begin{tabular}{|c} 
Persentase Selichih \\
Realicasi per Mingngu
\end{tabular} & $\begin{array}{c}\text { Bobot Rencana } \\
\text { Keseluruthan }\end{array}$ & Angaran Rencana & $\begin{array}{c}\text { ACWP/ } \\
\text { KONULATIF }\end{array}$ & ACWP/MINGGU \\
\hline 1 & 0,3689 & 0.3689 & 100,000 & $2231.681 ., 459,98$ & $8233.418,54$ & 8.233 .41854 \\
\hline 2 & 2,6116 & 2,2427 & 100,0000 & $2231.681 .459,98$ & 58282247,47 & $50.048 .828,93$ \\
\hline 3 & 6.3028 & 3,6912 & 100,0000 & $2231.681 .459,98$ & 140.657.493.91 & 82.375 .246 .4 \\
\hline 4 & 13,8046 & 7,5019 & 100,000 & $2.231 .681 .459,98$ & $308.075 .541,69$ & $167.418 .047,79$ \\
\hline 5 & 18,0857 & 4,2811 & 100,0000 & $2231.681 .459,98$ & $403.615 .092,4$ & $95539.550,74$ \\
\hline 6 & 24,7213 & 6,6336 & 100,0000 & $2231.681 .459,98$ & $551.700 .609,50$ & 148.0855.517,06 \\
\hline 7 & 38,259 & 135046 & 100,0000 & 2231.681.459,98 & $853.079 .664,81$ & $301.379 .655,31$ \\
\hline 8 & 47,1899 & 8.9640 & 100,0000 & $2231.681 . .599,98$ & 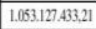 & 200.047 .768 .39 \\
\hline 9 & 538391 & 6,6992 & 100,000 & $2231.681 .459,98$ & $1.20151516 .198,11$ & $148.3887764,90$ \\
\hline 10 & $61556 ?$ & 7,7177 & 100,0000 & $2231.681 .459,98$ & $1.3737350,330,23$ & $172.234 .132,12$ \\
\hline II & 693927 & 7.8359 & 100,0000 & 2.231.681.459,98 & 1.548623.706,92 & $174.873 .376,69$ \\
\hline 12 & 76.8691 & 7,4764 & 100,000 & 2.231.681.459,98 & 1.715.473.874,89 & 166.850 .16797 \\
\hline 13 & 819610 & 5,0919 & 100,0000 & 22231.681.459,98 & 1.829.107.812.64 & 113.633997,75 \\
\hline 14 & 85,6539 & 3,6929 & 100,0000 & 2231.681..459,98 & 1.911.521.919,79 & $82.414 .107,15$ \\
\hline 15 & 88,2918 & 26779 & 10,0000 & $2231.681 .459,98$ & \begin{tabular}{|l}
$1.970391 .273,64$ \\
\end{tabular} & 58.869 .353 .85 \\
\hline 16 & 89,6553 & 1,3635 & 100,0000 & 2231.681..559,98 & \begin{tabular}{|l}
$20008.819 .720,90$ \\
\end{tabular} & $30,428.47 .26$ \\
\hline 17 & 903096 & 0,6543 & 100,0000 & $2231.681 .459,98$ & 2015.42.199,85 & $14,602478,95$ \\
\hline 18 & 923889 & 2,0993 & 100,0000 & $2231.681 .459,98$ & $2061.826 .647,30$ & $46,404.477,45$ \\
\hline 19 & $97.63 \pi$ & 5,2488 & 100,0000 & 2231.681..59998 & 21789622099,24 & $117.135 .561,94$ \\
\hline 20 & 100,0000 & 2.3623 & 100,0000 & 2.231.681.459,98 & 2.231.681.459,98 & 52.719 .250 .74 \\
\hline & & & & & & \\
\hline
\end{tabular}

Sumber : Hasil Perhitungan

\section{CV - Cost Variance}

$\mathrm{CV} \quad=\quad \mathrm{BCWP}-\mathrm{ACWP}$

Tabel 4. Nilai CV

\begin{tabular}{|r|r|r|r|}
\hline $\begin{array}{c}\text { Minggu } \\
\text { ke : }\end{array}$ & BCWP & ACWP & CV \\
\hline 1 & $9.056 .760,39$ & $8.233 .418,54$ & $823.341,85$ \\
\hline 2 & $55.053 .711,83$ & $50.048 .828,93$ & $5.004 .882,89$ \\
\hline 3 & $90.612 .771,08$ & $82.375 .246,44$ & $8.237 .524,64$ \\
\hline 4 & $184.159 .852,57$ & $167.418 .047,79$ & $16.741 .804,78$ \\
\hline 5 & $105.093 .505,82$ & $95.539 .550,74$ & $9.553 .955,07$ \\
\hline 6 & $162.894 .068,77$ & $148.085 .517,06$ & $14.808 .551,71$ \\
\hline 7 & $331.516 .960,84$ & $301.379 .055,31$ & $30.137 .905,53$ \\
\hline 8 & $220.052 .545,23$ & $200.047 .768,39$ & $20.004 .776,84$ \\
\hline 9 & $163.227 .641,39$ & $148.388 .764,90$ & $14.838 .876,49$ \\
\hline 10 & $189.457 .545,33$ & $172.234 .132,12$ & $17.223 .413,21$ \\
\hline 11 & $192.360 .714,36$ & $174.873 .376,69$ & $17.487 .337,67$ \\
\hline 12 & $183.535 .184,77$ & $166.850 .167,97$ & $16.685 .016,80$ \\
\hline 13 & $124.997 .331,52$ & $113.633 .937,75$ & $11.363 .393,77$ \\
\hline 14 & $90.655 .517,86$ & $82.414 .107,15$ & $8.241 .410,71$ \\
\hline 15 & $64.756 .289,23$ & $58.869 .353,85$ & $5.886 .935,38$ \\
\hline 16 & $33.471 .291,99$ & $30.428 .447,26$ & $3.042 .844,73$ \\
\hline 17 & $16.062 .726,85$ & $14.602 .478,95$ & $1.460 .247,90$ \\
\hline 18 & $51.044 .892,19$ & $46.404 .447,45$ & $4.640 .444,74$ \\
\hline 19 & $128.849 .118,13$ & $117.135 .561,94$ & $11.713 .556,19$ \\
\hline 20 & $57.991 .175,82$ & $52.719 .250,74$ & $5.271 .925,07$ \\
\hline & & & \\
\hline
\end{tabular}

Sumber : Hasil Perhitungan

\section{SV - Schedule Variance}

$\mathrm{SV} \quad=$ BCWP - BCWS

Tabel 5. Nilai SV

\begin{tabular}{|c|r|r|r|}
\hline $\begin{array}{c}\text { Minggu } \\
\text { ke : }\end{array}$ & BCWP & BCWS & SV \\
\hline \hline 1 & $9.056 .760,39$ & $7.493 .750,00$ & $1.563 .010,39$ \\
\hline 2 & $55.053 .711,83$ & $84.095 .219,38$ & $-29.041 .507,56$ \\
\hline 3 & $90.612 .771,08$ & $84.095 .219,38$ & $6.517 .551,70$ \\
\hline 4 & $184.159 .852,57$ & $112.491 .383,39$ & $71.668 .469,17$ \\
\hline 5 & $105.093 .505,82$ & $156.223 .444,11$ & $-51.129 .938,29$ \\
\hline 6 & $162.894 .068,77$ & $147.564 .858,78$ & $15.329 .209,99$ \\
\hline 7 & $331.516 .960,84$ & $103.832 .798,06$ & $227.684 .162,78$ \\
\hline 8 & $220.052 .545,23$ & $103.832 .798,06$ & $116.219 .747,17$ \\
\hline 9 & $163.227 .641,39$ & $58.179 .874,68$ & $105.047 .766,71$ \\
\hline 10 & $189.457 .545,33$ & $105.220 .344,73$ & $84.237 .200,61$ \\
\hline 11 & $192.360 .714,36$ & $75.436 .634,05$ & $116.924 .080,31$ \\
\hline 12 & $183.535 .184,77$ & $119.168 .694,77$ & $64.366 .490,00$ \\
\hline 13 & $124.997 .331,52$ & $101.911 .935,40$ & $23.085 .396,12$ \\
\hline 14 & $90.655 .517,86$ & $101.911 .935,40$ & $-11.256 .417,54$ \\
\hline 15 & $64.756 .289,23$ & $162.947 .069,10$ & $-98.190 .779,87$ \\
\hline 16 & $33.471 .291,99$ & $179.356 .545,41$ & $-145.885 .253,42$ \\
\hline 17 & $16.062 .726,85$ & $207.752 .709,42$ & $-191.689 .982,57$ \\
\hline 18 & $51.044 .892,19$ & $191.874 .557,35$ & $-140.829 .064,25$ \\
\hline 19 & $128.849 .118,13$ & $169.029 .182,38$ & $-40.180 .064,25$ \\
\hline 20 & $57.991 .175,82$ & $118.892 .503,82$ & $-60.901 .328,00$ \\
\hline & $2.454 .849 .605,98$ & $2.454 .849 .605,98$ & - \\
\hline & & & \\
\hline
\end{tabular}

Sumber : Hasil Perhitungan

\section{CPI - Cost Performance Index}

Tabel 6. Nilai CP1

\begin{tabular}{|c|r|r|}
\hline $\begin{array}{c}\text { Minggu } \\
\text { ke }:\end{array}$ & BCWP & \multicolumn{1}{|c|}{ ACWP } \\
\hline 1 & $9.056 .760,39$ & $8.233 .418,54$ \\
\hline 2 & $55.053 .711,83$ & $50.048 .828,93$ \\
\hline 3 & $90.612 .771,08$ & $82.375 .246,44$ \\
\hline 4 & $184.159 .852,57$ & $167.418 .047,79$ \\
\hline 5 & $105.093 .505,82$ & $95.539 .550,74$ \\
\hline 6 & $162.894 .068,77$ & $148.085 .517,06$ \\
\hline 7 & $331.516 .960,84$ & $301.379 .055,31$ \\
\hline 8 & $220.052 .545,23$ & $200.047 .768,39$ \\
\hline 9 & $163.227 .641,39$ & $148.388 .764,90$ \\
\hline 10 & $189.457 .545,33$ & $172.234 .132,12$ \\
\hline 11 & $192.360 .714,36$ & $174.873 .376,69$ \\
\hline 12 & $183.535 .184,77$ & $166.850 .167,97$ \\
\hline 13 & $124.997 .331,52$ & $113.633 .937,75$ \\
\hline 14 & $90.655 .517,86$ & $\mathbf{8 2 . 4 1 4 . 1 0 7 , 1 5}$ \\
\hline 15 & $64.756 .289,23$ & $58.869 .353,85$ \\
\hline 16 & $33.471 .291,99$ & $30.428 .447,26$ \\
\hline 17 & $16.062 .726,85$ & $14.602 .478,95$ \\
\hline 18 & $51.044 .892,19$ & $46.404 .447,45$ \\
\hline 19 & $128.849 .118,13$ & $117.135 .561,94$ \\
\hline 20 & $57.991 .175,82$ & $52.719 .250,74$ \\
\hline & $2.454 .849 .605,98$ & $2.231 .681 .459,98$ \\
\hline & & \\
\hline & & \\
\hline & & \\
\hline & & \\
\hline
\end{tabular}

Sumber : Hasil Perhitungan

CPI $=\frac{\sum B C W P}{\sum A C W P}=\frac{2.454 .849 .605,98}{2.231 .681 .459,98}$

2.231 .68
$=1.1000$ 
SPI - Schedule Performance Index

Tabel 7. Nilai SP1

\begin{tabular}{|r|r|r|}
\hline $\begin{array}{c}\text { Minggu } \\
\text { ke : }\end{array}$ & BCWP & \multicolumn{1}{c|}{ BCWS } \\
\hline 1 & $9.056 .760,39$ & $7.493 .750,00$ \\
\hline 2 & $55.053 .711,83$ & $84.095 .219,38$ \\
\hline 3 & $90.612 .771,08$ & $84.095 .219,38$ \\
\hline 4 & $184.159 .852,57$ & $112.491 .383,39$ \\
\hline 5 & $105.093 .505,82$ & $156.223 .444,11$ \\
\hline 6 & $162.894 .068,77$ & $147.564 .858,78$ \\
\hline 7 & $331.516 .960,84$ & $103.832 .798,06$ \\
\hline 8 & $220.052 .545,23$ & $103.832 .798,06$ \\
\hline 9 & $163.227 .641,39$ & $58.179 .874,68$ \\
\hline 10 & $189.457 .545,33$ & $105.220 .344,73$ \\
\hline 11 & $192.360 .714,36$ & $75.436 .634,05$ \\
\hline 12 & $183.535 .184,77$ & $119.168 .694,77$ \\
\hline 13 & $124.997 .331,52$ & $101.911 .935,40$ \\
\hline 14 & $90.655 .517,86$ & $101.911 .935,40$ \\
\hline 15 & $64.756 .289,23$ & $162.947 .069,10$ \\
\hline 16 & $33.471 .291,99$ & $179.356 .545,41$ \\
\hline 17 & $16.062 .726,85$ & $207.752 .709,42$ \\
\hline 18 & $51.044 .892,19$ & $191.874 .557,35$ \\
\hline 19 & $128.849 .118,13$ & $169.029 .182,38$ \\
\hline 20 & $57.991 .175,82$ & $118.892 .503,82$ \\
\hline & $2.454 .849 .605,98$ & $\mathbf{2 . 3 9 1 . 3 1 1 . 4 5 7 , 6 8}$ \\
\hline
\end{tabular}

Sumber : Hasil Perhitungan

SPI $=\frac{\sum B C W P}{\sum B C W S}=\frac{2.454 .849 .605,98}{2.391 .311 .457,68}$ $=1.0266$

\section{ETC - Estimate to Completion}

Tabel 8. Nilai ETC

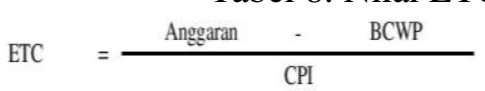

\begin{tabular}{|c|c|c|c|c|}
\hline $\begin{array}{c}\text { Minggu } \\
\text { ke : }\end{array}$ & ANGGARAN & BCWP & CPI & ETC \\
\hline 1 & $2.454 .849 .605,98$ & $9.056 .760,39$ & 1,1000 & $2.223 .448 .041,44$ \\
\hline 2 & $2.454 .849 .605,98$ & $55.053 .711,83$ & 1,1000 & 2.181.632.631,05 \\
\hline 3 & $2.454 .849 .605,98$ & $90.612 .771,08$ & 1,1000 & $2.149 .306 .213,55$ \\
\hline 4 & $2,454.849 .605,98$ & $184.159 .852,57$ & 1,1000 & $2.064 .263 .412,19$ \\
\hline 5 & $2.454 .849 .605,98$ & $105.093 .505,82$ & 1,1000 & $2.136 .141 .909,24$ \\
\hline 6 & $2.454 .849,605,98$ & $162.894 .068,77$ & 1,1000 & 2.083.595.942,92 \\
\hline 7 & 2.454 .849 .605 .98 & 331.516 .960 .84 & 1,1000 & $1.930 .302 .404,67$ \\
\hline 8 & 2.454.849.605,98 & $220.052 .545,23$ & 1,1000 & 2.031.633.691,59 \\
\hline 9 & $2.454 .849 .605,98$ & $163.227 .641,39$ & 1,1000 & $2.083 .292 .695,08$ \\
\hline 10 & $2.454 .849 .605,98$ & $189.457 .545,33$ & 1,1000 & $2,059.447 .327,86$ \\
\hline 11 & $2.454 .849 .605,98$ & $192.360 .714,36$ & 1,1000 & $2.056 .808 .083,29$ \\
\hline 12 & $2.454 .849 .605,98$ & $183.535 .184,77$ & 1,1000 & $2.064 .831 .292,01$ \\
\hline 13 & $2.454 .849 .605,98$ & $124.997 .331,52$ & 1,1000 & $2.118 .047 .522,23$ \\
\hline 14 & $2.454 .849 .605,98$ & $90.655 .517,86$ & 1,1000 & 2.149.267.352,83 \\
\hline 15 & $2.454 .849 .605,98$ & $64.756 .289,23$ & 1,1000 & $2.172 .812 .106,13$ \\
\hline 16 & $2.454 .849 .605,98$ & $33.471 .291,99$ & 1,1000 & $2.201 .253 .012,72$ \\
\hline 17 & $2.454 .849 .605,98$ & $16.062 .726,85$ & 1,1000 & $2.217 .078 .981,03$ \\
\hline 18 & $2.454 .849 .605,98$ & $51.044 .892,19$ & 1,1000 & $2.185 .277 .012,54$ \\
\hline 19 & $2.454 .849 .605,98$ & $128.849 .118,13$ & 1,1000 & $2.114 .545 .898,04$ \\
\hline 20 & $2.454 .849 .605,98$ & $57.991 .175,82$ & 1,1000 & $2.178 .962 .209,24$ \\
\hline
\end{tabular}

Sumber : Hasil Perhitungan

\section{EAC - Estimate at Completion}

Tabel 9. Nilai EAC

\begin{tabular}{|c|c|c|c|}
\hline $\begin{array}{l}\text { Minggu } \\
\text { ke : }\end{array}$ & ACWP & ETC & EAC \\
\hline$T$ & $8.233 .418,54$ & $2.223 .448 .041,44$ & $2.231 .681 .459,98$ \\
\hline 2 & $50.048 .828,93$ & $2.181 .632 .631,05$ & $2.231 .681 .459,98$ \\
\hline 3 & $82.375 .246,44$ & $2.149 .306 .213,55$ & $2.231 .681 .459,98$ \\
\hline 4 & $167.418 .047,79$ & $2.064 .263 .412,19$ & $2.231,681.459,98$ \\
\hline 5 & $95.539,550,74$ & $2,136.141 .909,24$ & $2.231 .681,459,98$ \\
\hline 6 & $148.085 .517,06$ & $2.083 .595 .942,92$ & $2.231,681,459,98$ \\
\hline 7 & $301.379 .055,31$ & $1.930 .302 .404,67$ & $2.231 .681 .459,98$ \\
\hline 8 & 200.047 .768 .39 & $2.031 .633 .691,59$ & $2.231 .681 .459,98$ \\
\hline 9 & $148.388 .764,90$ & $2.083 .292 .695,08$ & $2.231,681.459,98$ \\
\hline 10 & $172.234 .132,12$ & $2,059.447 .327,86$ & $2.231 .681 .459,98$ \\
\hline 11 & $174.873 .376,69$ & $2.056 .808 .083,29$ & $2.231 .681 .459,98$ \\
\hline 12 & $166.850 .167,97$ & $2.064 .831 .292,01$ & $2.231 .681 .459,98$ \\
\hline 13 & $113.633 .937,75$ & $2.118 .047 .522,23$ & $2.231 .681 .459,98$ \\
\hline 14 & $82.414 .107,15$ & $2.149 .267 .352,83$ & $2.231 .681 .459,98$ \\
\hline 15 & $58.869 .353,85$ & $2.172 .812 .106,13$ & $2.231 .681 .459,98$ \\
\hline 16 & $30.428 .447,26$ & $2.201 .253 .012,72$ & $2.231 .681,459,98$ \\
\hline 17 & $14.602 .478,95$ & $2.217 .078 .981,03$ & $2.231 .681 .459,98$ \\
\hline 18 & 46.404.447,45 & $2.185 .277 .012,54$ & $2.231 .681 .459,98$ \\
\hline 19 & $117.135 .561,94$ & $2.114 .545 .898,04$ & $2.231 .681 .459,98$ \\
\hline 20 & $52.719 .250,74$ & $2.178 .962,209,24$ & $2.231 .681 .459,98$ \\
\hline
\end{tabular}

Sumber : Hasil Perhitungan

\section{ECD - Estimated Completion Date \\ Tabel 10. Nilai ECD \\ ECD $=\frac{\text { Sisa Waktu }}{\text { SPI }}+$ Waktu Terpakai}

\begin{tabular}{|c|r|c|c|c|}
\hline $\begin{array}{c}\text { Minggu } \\
\text { ke }:\end{array}$ & SISA WAKTU & SPI & WAKTU TERPAKAI & ECD \\
\hline \hline 1 & 143.00 & 1.2086 & 7.0000 & 126 \\
\hline 2 & 136.00 & 0.6547 & 14.0000 & 222 \\
\hline 3 & 129.00 & 1.0775 & 21.0000 & 141 \\
\hline 4 & 122.00 & 1.6371 & 28.0000 & 103 \\
\hline 5 & 115.00 & 0.6727 & 35.0000 & 206 \\
\hline 6 & 108.00 & 1.1039 & 42.0000 & 140 \\
\hline 7 & 101.00 & 3.1928 & 49.0000 & 81 \\
\hline 8 & 94.00 & 2.1193 & 56.0000 & 101 \\
\hline 9 & 87.00 & 2.8056 & 63.0000 & 95 \\
\hline 10 & 80.00 & 1.8006 & 70.0000 & 115 \\
\hline 11 & 73.00 & 2.5500 & 77.0000 & 106 \\
\hline 12 & 66.00 & 1.5401 & 84.0000 & 127 \\
\hline 13 & 59.00 & 1.2265 & 91.0000 & 140 \\
\hline 14 & 52.00 & 0.8895 & 98.0000 & 157 \\
\hline 15 & 45.00 & 0.3974 & 105.0000 & 219 \\
\hline 16 & 38.00 & 0.1866 & 112.0000 & 316 \\
\hline 17 & 31.00 & 0.0773 & 119.0000 & 520 \\
\hline 18 & 24.00 & 0.2660 & 126.0000 & 217 \\
\hline 19 & 17.00 & 0.7623 & 133.0000 & 156 \\
\hline 20 & 10.00 & 0.4878 & 140.0000 & 161 \\
\hline & & & & \\
\hline & & & & \\
\hline
\end{tabular}

Sumber : Hasil Perhitungan

\section{Hasil Pembahasan}

Berdasarkan hasil perhitungan dari indikator indikator yang digunakan diatas, maka kondisi yang terjadi pada proyek Pembangunan Gedung Satpol PP Kabupaten Majalengka dapat diuraikan sebagai berikut : \begin{tabular}{lrr} 
1. Pelaksanaan proyek & \multicolumn{2}{c}{ konstruksi } \\
Pembangunan Gedung Satpol PP
\end{tabular} Kabupaten Majalengka yang rencana 
pengerjaan selama 22 Minggu terlihat Hasil perhitungan BCWS (Budgeted Cost for Work Scheduled) sampai minggu terakhir = Rp 20.082.278,54 BCWP (budgeted Cost for Work Performed) sampai minggu terakhir $=\mathrm{Rp}$. 57.991.175,82, serta ACWP (Actual Cost for Performed) sampai minggu terakhir = Rp. 52.719.250,74 artinya nilai BCWS < BCWP. Ini menunjukan bahwa proyek tersebut lebih cepat dari rencana semula. Nilai ACWP $>$ BCWS $<$ BCWP menunjukan bahwa biaya aktual yang dikeluarkan lebih besar dari rencana anggaran biaya (RAB) dan lebih kecil dari biaya penyelesaian volume pekerjaan, sehingga terjadi penghematan. Nilai hasil (earned value) pada waktu pengerjaan sangat baik karena BCWP > ACWP, artinya cashflow proyeknya lancar.

2. Hasil perhitungan CV (Cost Variance) sampai minggu terakhir Rp. 5.271.925,07 yang artinya pada bulan Juli sampai bulan Nopember menunjukkan angka positif, hal ini berarti biaya untuk menyelesaikan proyek lebih kecil dari rencana Rp. 52.719.250,74.

3. Hasil perhitungan SV (Schedule Variance) di minggu pertama Rp. 1.563.010,39 menunjukkan angka positif, hal ini berarti pelaksanaan lebih cepat dari yang direncanakan ( BCWS ) Rp. 7.493.750,00 dengan realisasi (BCWP) sebesar Rp. 9.056.760,39 . meskipun minggu terakhir angka negatif, tetapi jumlah keseluruhan pada bulan Juli sampai bulan Nopember lebih cepat dari rencana sebesar Rp.2.391.311.457,68.

4. Hasil perhitungan CPI (Cost Performance Index) sebesar 1,1000 didapat dari perhitungan $\quad \frac{\sum B C W P}{\sum A C W P}=\frac{2454.849,605,98}{2.231 .681 .459,98}$ $=1,1000$. Nilai CPI ini menunjukkan bobot nilai yang diperoleh terhadap biaya yang dikeluarkan. CPI lebih dari 1 menunjukkan kinerja biaya yang baik, karena biaya yang dikeluarkan (ACWP) lebih kecil dibanding dengan nilai yang didapat (BCWP), dalam arti pengeluaran lebih kecil dari anggaran perencanaan dan kegiatan pelaporan dari pengawasan lapangan berjalan lancar.

5. Hasil perhitungan SPI (Schedule Performance Index) sebesar 1,0266

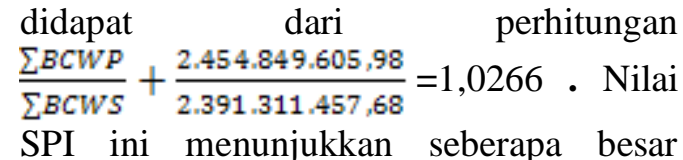
pekerjaan yang mampu diselesaikan terhadap satuan pekerjaan yang direncanakan. Nilai SPI lebih dari 1 menunjukkan bahwa kinerja pekerjaan (BCWP) berjalan lebih cepat dari rencana pekerjaan (BCWS).

6. Nilai EAC (Estimate At Completion) sebesar Rp. 2.231.681.459,98 menunjukkan perkiraan total biaya pelaksanaan proyek Pembangunan Gedung Satpol PP Kabupaten Majalengka dari rencana anggaran biaya pelaksanaan sebesar Rp. 2.454.849.000 dengan menyisakan anggaran sebesar Rp. 223.167.540 .

7. Nilai ECD (Estimate Completion Date) sebesar 126, menunjukkan perkiraan waktu penyelesaian konstruksi selama 126 hari yang artinya proyek mengalami kemajuan waktu selama 24 hari dari rencana 150 hari.

\section{KESIMPULAN DAN SARAN}

Kesimpulan hasil analisis dengan menggunakan metode Konsep Nilai Hasil terhadap biaya dan waktu proyek pembangunan Gedung Satpol PP Kabupaten Majalengka sampai minggu ke -22 dengan anggaran sebesar Rp. 2.454.849.000,- (Dua Miliar empat ratus lima puluh empat juta delapan ratus empat puluh sembilan ribu rupiah) dapat disimpulkan sebagai berikut :

1. Analisa Pengendalian Biaya dan Waktu menggunakan metode Konsep Nilai Hasil pada Proyek Pembangunan Gedung Satpol PP Kabupaten Majalengka sangat efektif terlihat pada adanya sisa anggaran proyek dan waktu penyelesaian proyek lebih cepat dari rencana pelaksanaan dengan rincian di bawah ini :

a) Indeks Kinerja Biaya dan Waktu

Indeks Kinerja Biaya (CPI), diperoleh sebesar 1,1000, didapat dari perhitungan $\frac{\sum B C W P}{\sum A C W P}=\frac{2.454 .849,605,98}{2.231 .681_{0} 459,98} \quad=1,1000$.

Nilai CPI ini menunjukkan bobot nilai yang diperoleh terhadap biaya yang dikeluarkan. CPI lebih dari 1 menunjukkan kinerja biaya yang baik, karena biaya yang dikeluarkan (ACWP) 
lebih kecil dibanding dengan nilai yang didapat (BCWP), dalam arti pengeluaran lebih kecil dari anggaran perencanaan dan kegiatan pelaporan dari pengawasan lapangan berjalan lancar.

Indeks Kinerja Waktu (SPI) diperoleh sebesar 1,0266, didapat dari perhitungan $\frac{\sum B C W P}{\sum B C W S}+\frac{2,454.849 .605,98}{2,391.311 .457,68}=1,0266$. Nilai SPI ini menunjukkan seberapa besar pekerjaan yang mampu diselesaikan terhadap satuan pekerjaan yang direncanakan. Nilai SPI lebih dari 1 menunjukkan bahwa kinerja pekerjaan (BCWP) berjalan lebih cepat dari rencana pekerjaan (BCWS).

b) Prediksi Biaya dan Waktu

Perkiraan biaya penyelesaian proyek (EAC) adalah Rp. 2.23.681.459,98 Hal ini menunjukkan bahwa biaya yang dikeluarkan lebih kecil dari anggaran pelaksanaan, dengan total anggaran biaya pelaksanaan sebesar Rp 2.454.849.000 dengan menyisakan anggaran sebesar Rp. 223.167.540.

Perkiraan waktu penyelesaian proyek (ECD) sebesar 126, menunjukkan perkiraan waktu penyelesaian konstruksi selama 126 hari yang artinya proyek mengalami kemajuan waktu selama 24 hari dari rencana 150 hari.

\section{REFERENSI}

Arpan, M., 2014, Evaluasi Keterlambatan Proyek Menggunakan Metode Konsep Nilai Hasil, Tugas Akhir, (Tidak Diterbitkan), Universitas Islam Indonesia, Yogyakarta.
Daulasih dkk, 2016, Perbandingan Biaya Proyek Gedung Empat Lantai STKIP KIE RAHA Ternate dengan Metode Earned Value, Skripsi, UNiversitas Sam Ratulangi, Manado.

Dinariana dan Mirawati., 2011, Evaluasi Pengendalian Biaya dan Waktu dengan Menggunakan Metode Earned Value pada Proyek Student Boarding House President University, Jurnal, Universitas Persada Indonesia YAI, Jakarta.

Ervianto,W.I, 2002, Manajemen Proyek Konstruksi, Penerbit Andi Yogyakarta, Yogyakarta.

Filastri, 2015, Analisis Biaya dan Waktu Proyek Pembangunan Kampus Politeknik Menggunakan Konsep Earned Value, Skripsi, Universitas Hasanuddin, Makasar.

Mockler, R.J., 1972, Management Control Process, Prentice Hall, New York.

Noegroho, 2014, Peningkatan Kualitas Pembuatan Keputusan dan Pengendalian Kemajuan Pelaksanaan Proyek Menggunakan Analisis Earned Value, Skripsi.

Soeharto, Iman. 1995. Manajemen Proyek Dari Konseptual Sampai Operasional.Jakarta.

Soemardi B.W, dkk., 2007 Konsep Earned Value untuk Pengelolaan Proyek Konstruksi,(Online)

Suhermanto, A., 2014, Analisis Perencanaan Biaya dan Waktu Penyelesaian Proyek dengan Metode Konsep Nilai Hasil, Tugas Akhir, (Tidak Diterbitkan), Universitas Islam Indonesia, Yogyakarta.

Widiasantri, I. dan Linggogeni, (2013), Manajemen Konstruksi, Penerbit Rosda. 